\title{
Bioactive Glass: Regeneration in Critical Size Defects in Tibia of Animal Models
}

\author{
Maria Khan ${ }^{1}$ \\ Sarah Ghafoor ${ }^{2}$
}

\author{
BDS \\ BDS, BSc, PhD
}

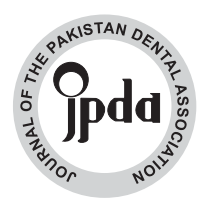

Bioactive glasses (BGs) is a synthetic osteoinductive material that has characteristic feature to form an interfacial linkage between an implant and host tissue. It is classified as third generation biomaterials and has ability to bond to hard as well as soft tissue. It simulates bone formation through dissolution of ions during the degradative process of BG, which induce osteogenic gene expression leading to enhanced bone regeneration. Therefore, BGs have shown great applications in the field of bone regeneration, tissue engineering, dental materials, and periodontal regeneration. This review is specifically based on performance of BG scaffolds being used in tibial bone regeneration in animal models. The relationship of critical size defect and tibial regeneration has been highlighted where BGs have been used as synthetic bone graft materials. It was found that BGs showed enhanced osteogenic properties without any toxicity. There has been significant research work performed on micro-particles bioactive glasses but not much literature can be found on nano-particles bioactive glasses, which can show better osteogenic properties due to high surface area and better adaptability with hard tissue structure.

KEY WORDS: Tibia, Bone, Regeneration, Bioactive glass, Animal models.

HOW TO CITE: Khan M, Ghafoor S. Bioactive glass: regeneration in critical size defects in tibia of animal models . J Pak Dent Assoc 2019;28(3):136-142.

DOI: https://doi.org/10.25301/JPDA.283.136

Received: 05 December 2018, Accepted: 03 May 2019

\section{INTRODUCTION}

$\mathrm{B}$ one is a constantly remodeling, dense, regular, calcified, and brittle connective tissue. By composition, it is a calcified tissue in which mineral component is hydroxyapatite (HA). Bone remodeling is a continuous, systematic, tightly regulated physiological ongoing process throughout life. Pathology, trauma or iatrogenic factors may cause discontinuity in bone structure that gets repaired which leads to continuity in structure but not function. Bone regeneration, on the other hand, is a wellorchestrated spatio-temporal phenomenon under strict molecular regulation leading to complete physiological, morphological and structural continuity. ${ }^{1}$

\section{CRITICAL SIZED DEFECT}

Bone may get fractured or injured in a variety of ways during life. Usually it repairs itself but in certain cases the defect can be so large that the body is not able to regain the same form and function as that before injury. ${ }^{2}$ The orthotopic defects of bone which do not heal during life-time span of an individual without an external intervention are called as critical size defect. The dimensional variations for each bone

1. MPhil Trainee, Department of Oral Biology, University of Health Sciences, Lahore 2. Assistant Professor, Department of Oral Biology, University of Health Sciences, Lahore. Corresponding author: "Dr. Sarah Ghafoor” < sarahghafoor@uhs.edu.pk > to be categorized as critical are different. ${ }^{3}$ In such cases, to mediate bone regeneration, strategies like Guided Bone Regeneration, bone replacement grafts, autograft (gold standard), allografts, xenografts, stem cell regeneration are employed. ${ }^{4}$

\section{BONE REGENERATING MATERIALS}

Most prevalent and successful technique to date is autologous bone graft and iliac crest graft due to minor or major infections, neurologic or vascular injuries, arteriovenous fistula, hematoma etc. at either donor or harvesting sites. ${ }^{5}$ Xeno-transplantation involves cross-transplant between humans and other species. Although it allows for sufficient donors and promises life saving benefits but then chances of cross-infection and ethical concerns reprimand it to be used frequently. ${ }^{5,6}$ Allografting is intraspecies exchange of tissuesfrom either cadaver or living body after sterilization and processing. While it offers viability, safer mode, less surgical intervention and good succes rate but graft rejection, expensive treatment, delayed wound healing and functional rejection may pose inefficiency. ${ }^{7,8}$ Bone regeneration can involve osteogenesis (autologous bone graft), osteoinduction and osteoconduction. The technique is based upon replacement of biomimetic material with living tissue as it starts to resorb iself providing basis and space for living tissue to ingrow. ${ }^{9}$ 
Biomaterials, so far have evolved through three chronological phases. The first type was bioinert materials which were least reactive and less corrosive generally for industrial use. Then second generation was developed which comprised of materials bearing properties of biodegradability and bioactivity, thus providing with 'biomimetics' that we use today. The third generation material developed was conceptual and theoretically it could guide and modify cellular functions at molecular level. ${ }^{10}$ This makes bioactive biomaterials a promising candidate for the reconstruction of calcified tissues of human body including tooth and bone. ${ }^{11}$ However, it is important to understand bioactivity or biological activity of a biomaterial. For that, the focus of biological activity is related to entity and expression can be stated to be: (1) what it is; (2) what it does, and (3) how much of it is present. ${ }^{12}$

\section{BIOACTIVITY}

Bioactivity can be classified into two types as tabulated in Table 1, which depend upon the rate of tissue response to the implants. Class A bioactivity is the most rapid bonding to hard tissue and it also bond to soft connective tissues. Class A bioactive materials produce bone throughout the particle array, and it is known as osteoproduction. These materials also exhibit osteoconduction, which is defined as "The process of bond migration along a biocompatible surface". Class B bioactive material such as synthetic HA shows only osteoconduction. Therefore, they lead to a very slow bond to bone and incomplete proliferation of bone throughout a particular array. ${ }^{13}$

The bioactive ceramics, one of the second group of materials developed, not only have been useful in bone repairs and replacements, but also are inspiring new bioactive materials. ${ }^{14,15}$ Bioceramics such as calcium phosphate (hydroxyapatite, tricalcium phosphates, and dicalcium phosphates) and bioactive glasses have been used for biomedical applications. Calcium phosphate based materials are osteoconductive, whereas bioactive glass materials contain the advantageous properties of osteonductivity and osteoinductivity. ${ }^{16,17}$

\section{BIOACTIVE GLASS}

Larry Hench and co-workers developed a ceramic-based new class of materials known as "Bioactive Glasses" in $1969^{18}$ which were capable of interacting with living host soft and hard tissues by promoting stable biological linkages and chemical bonds. ${ }^{19}$ Upon interaction with bodily fluids its components phosphorus and calcium impregnate into silicon rich surface layer of the material. ${ }^{20} 45 \mathrm{~S} 5$ Bioglass ${ }^{\circledR}$ $\left(45 \mathrm{SiO}_{2}-24.5 \mathrm{CaO}-24.5 \mathrm{Na}_{2} \mathrm{O}-6 \mathrm{P}_{2} \mathrm{O}_{5}\right)$ is the traditional bioactive glass that had later many modifications in it in terms of ratios and compositions each rendering its own specific properties to the material. 45S5 Bioglass ${ }^{\circledR}$ allows osteoblasts to become alkalinized leading to deposition of collagen and hydroxyapatite formation upon bone surface..$^{21}$ Similarly, BG60S (silica $60 \%$, calcium $35 \%$, phosphate $5 \%$ ) allows the osteoblast vacuole formation ${ }^{22}$ promoting bone deposition. With variations in composition and consistency of the bioactive glass there is also a demonstration of bacteriostatic activity in-vitro. ${ }^{23}$ In addition, it has been suggested how bioactive glass can initiate bone regeneration in animal model at a rate that even surpassed encapsulation by epithelialization. ${ }^{24} \mathrm{~S} 53 \mathrm{P} 4\left(53 \mathrm{SiO}_{2}-20 \mathrm{CaO}-23 \mathrm{Na}_{2} \mathrm{O}-4 \mathrm{P}_{2} \mathrm{O}_{5}\right)$ is a product besides conventional $45 \mathrm{~S} 5$ composition that has been allowed for use in medical purpose as bone substitute. ${ }^{25}$ Still many obstacles, shortcomings and frontiers need to be passed to actually make these beneficial to patients. Various studies have been conducted to evaluate the behavior of bioactive glass in animal models ${ }^{26-29}$ and critical size defects have been created and bioactive glass in the form of spherical particles, granules and pallets have been used. ${ }^{30}$

Histologically, rats differ from human bones as they do not have a haversian system therefore, cellular organization is different. ${ }^{31}$ Innately, rats continue to have their property of bone regeneration almost throughout their adult life. Among multiple critical size defects that have been experimented upon animal models, tibial defect is one of most important. Critical size defects in tibial bone can relate to large defects in maxillofacial bones that can occur as a result of injury or disease such as bone resection during cancer therapy. Such large defects in facial bones cannot heal on their own leaving a life-long impairment to the patient quality of life both functionally and psychologically. Thus understanding biomaterials that can be related to therapeutic purpose for filling of critical size defects can lead clinicians towards understanding materials for filling defects in maxillofacial bones.

In this regards, authors could not find any review study where the relation of critical size defect in tibial bone has been discussed in relation to bioactive glasses. It is expected that this review paper will provide an updated information with respect to application of bioactive glasses in tibial defect area.

\section{APPLICATION OF BIOACTIVE GLASSES IN TIBIAL DEFECTS}

Cui et $\mathrm{al}^{32}$ induced osteomyelitis in New Zealand White rabbits by injecting Staphylococcus aureus suspension, sodium morrhate and PBS into the rabbit tibiae. A cortical 
bone window ( $2 \mathrm{~mm} \times 8 \mathrm{~mm})$ was prepared, and injectable vancomycin-loaded borate bioactive glass $\left(6 \mathrm{Na}_{2} \mathrm{O} .8 \mathrm{~K}_{2} \mathrm{O} .8 \mathrm{MgO} .22 \mathrm{CaO} .54 \mathrm{~B}_{2} \mathrm{O}_{3} \cdot 2 \mathrm{P}_{2} \mathrm{O}_{5}\right)$ cement was injected. In other group of rabbits, vancomycin-loaded calcium sulphate cement was injected. Both these groups were compared with non-loaded bone cavity. After 8 weeks of implantation, the results showed the calcium sulphatebased cements exhibited presence of fibrous tissue on the surface of the implant, whereas, borate bioactive glass cements showed the presence of newly formed apatite layer and attachment of proteins to the surface of apatite subsequently formation of bone-like tissue as shown in Fig. 1. Histological analysis also confirmed these results and new bone appeared to be well bonded to the implant and the defected bone area was filled with connective tissue.

(C) Copyright with permission, Cui X, Zhao C, Gu Y, Li L, Wang H, Huang $W$, et al. A novel injectable borate bioactive glass cement for local delivery of vancomycin to cure osteomyelitis and regenerate bone. J Mater Sci Mater Med. 2014; 25(3): 733-745.

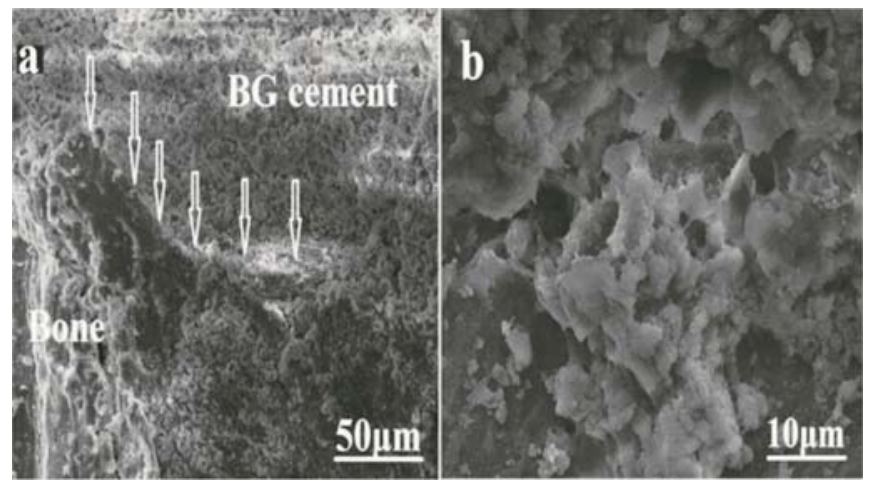

Fig 1 (a): SEM image of a rabbit tibial defect implanted with vancomycin- loaded borate bioactive glass cement for 8 weeks and showed conversion of borate glass resulted in fairly dense implant integrated with host tissue. The arrows indicate the bone-implant interface, (b) SEM image of longitudinal section of implanted rabbit tibia showed the conversion of borate bioactive glass to HA and attachment of proteins to the surface of HA resulted in formation of a bone-like tissue.

In another study, osteomyelitis was induced and the bone cavities were filled with teicoplanin-loaded borate bioactive glass $\left(6 \mathrm{Na}_{2} \mathrm{O}, 8 \mathrm{~K}_{2} \mathrm{O}, 8 \mathrm{MgO}, 22 \mathrm{CaO}, 54 \mathrm{~B}_{2} \mathrm{O}_{3}\right.$, and $\left.2 \mathrm{P}_{2} \mathrm{O}_{5}\right)$ and calcium sulphate beads respectively. The morphology of newly formed bone was sponge-like structure, similar to human trabecular bone. Vascular tissue was distributed in both new bone and grafted glass, further, micropores $(5-10 \mu \mathrm{m})$ were also observed resulting due to glass conversion. The factors which help in bone healing include geometry, surface chemistry, and porous structure. In case of bioactive glass, osteoconduction is the main attributing factor and ion release of bioactive glass, which leads to conversion of glass to HA-like layer. This also promotes the in growth of vascular tissue into the bioactive materials. ${ }^{33}$

In another study ${ }^{34}$, teicoplannin-loaded borate bioactive glass $\left(6 \mathrm{Na}_{2} \mathrm{O}, 8 \mathrm{~K}_{2} \mathrm{O}, 8 \mathrm{MgO}, 22 \mathrm{CaO}, 54 \mathrm{~B}_{2} \mathrm{O}_{3}\right.$, and $\left.2 \mathrm{P}_{2} \mathrm{O}_{5}\right)$ was implanted for 12 weeks in osteomyelitis induced rabbit tibia. After 12 weeks implantation no infection and complications were found and conversion into HA layer was observed and comparative XRD pattern and SEM analysis showed fairly dense, firmed connection of newly regenerated and old bone. Osteoclasts adhered to the rough surface of newly formed HA layer attempted to break down calcium and phosphorous. Furthermore, there was concern about toxicity of boron in bioactive glass which decreased within 7-10 days.

Moimas et $\mathrm{al}^{35}$ synthesized cylindrical $(8 \mathrm{~mm}$ in length x $3.75 \mathrm{~mm}$ diameter) bioactive glass $\left[\mathrm{Na}_{2} \mathrm{O}(6 \mathrm{wt} . \%), \mathrm{K}_{2} \mathrm{O}\right.$ (12wt.\%), $\mathrm{MgO}$ (5wt. \%), $\mathrm{CaO}$ (20wt.\%), $\mathrm{P}_{2} \mathrm{O}_{5} 4$ wt.\%), and $\left.\mathrm{SiO}_{2}(53 \mathrm{wt} . \%)\right]$ fibers scaffold were prepared and placed in tibia of New Zealand White rabbits in control and compared with morsels and PerioGlas ${ }^{\circledR}$ (Novabone, Jacksonville, FL, USA). After 6 months, the visual examination showed healthy tibial bone without inflammation. The tomography showed (Fig. 2) that defect reduced up to $3 \mathrm{~mm}$, as scaffold acted as

(C) Copyright with permission, Moimas L, Biasotto M, Lenarda RD, Olivo A, Schmid C. Rabbit pilot study on the resorbability of threedimensional bioactive glass fibre scaffolds. Acta Biomater. 2006; 2(2): 191-9.

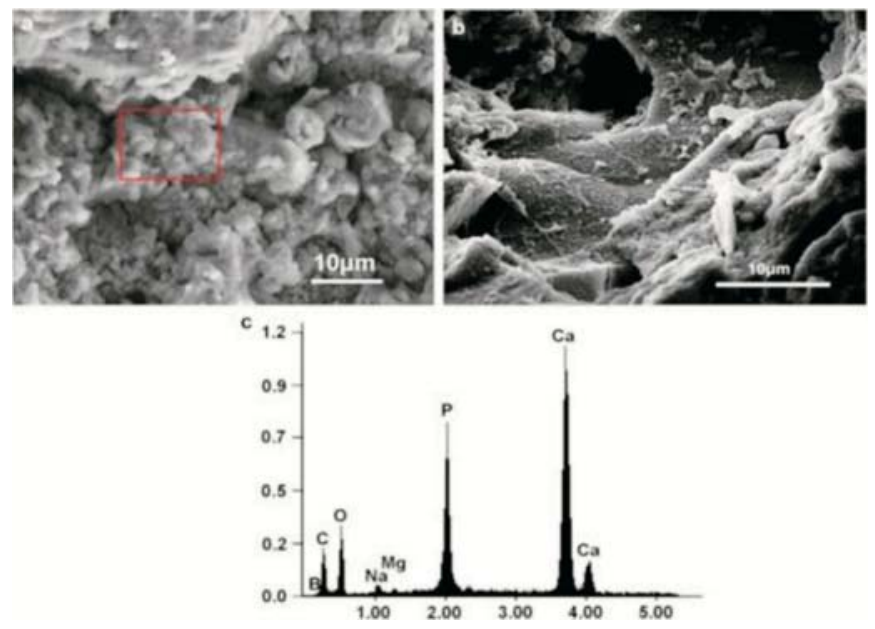

Fig 2: SEM images of teicoplanin-loaded borate bioactive glass (TBDC) pellets after implantation for 12 weeks in a rabbit tibia osteomyelitis model The conversion of teicoplanin loaded borate bioactive glass was connected firmly with the old bone or with the regenerated bone within the 12-week implantation period, where (a) dense structure of regenerative bone was formed, (b) the cells appeared to attach firmly to the surface of the pores, even for the well compacted regions of the implants (c) Microchemical analysis of the boxed area (a) using energy dispersive X-ray (EDS) analysis in the SEM showed a calcium to phosphorus $(\mathrm{Ca} / \mathrm{P})$ atomic ratio of 1.54 , which is lower than the value (1.67) for stoichiometric HA. (image taken after permission from authors) 
(C) Copyright with permission, Zhang X, Jia W, Gu Y, Xiao W, Liu X, Wang D, et al. Teicoplanin-loaded borate bioactive glass implants for treating chronic bone infection in a rabbit tibia osteomyelitis model. Biomaterials. 2010; 31(22): 5865-5874.

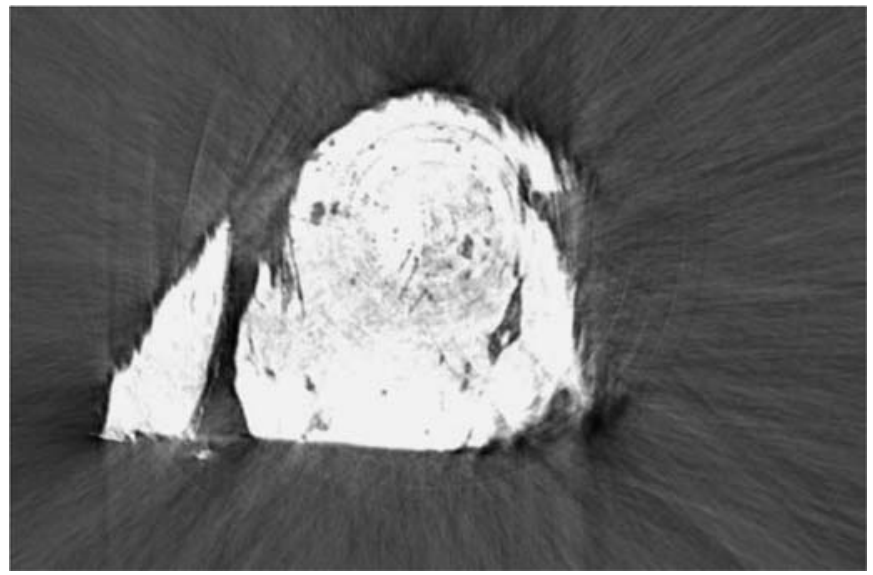

Fig 3: 2D reconstructed section of a defect filled with glass fiber scaffold with a porosity of $55-60 \%$ on the surface of the defect, newly formed cortical bone in the defect surface. (image taken after permission from authors)

osteoconductive matrix. This study concluded that three dimensional implants are more effective than PerioGlas ${ }^{\circledR}$ particles.

Gorustovich et $\mathrm{al}^{36}$ created defect ( $1.5 \mathrm{~mm}$ diameter) in rat tibiae adding $2 \%$ boron-45S5 bioactive glass $\left(\mathrm{SiO}_{2}\right.$, $\mathrm{CaCO}_{3}, \mathrm{Na}_{2} \mathrm{CO}_{3}, \mathrm{CaHPO}_{4} \cdot 2 \mathrm{H}_{2} \mathrm{O}$ and $\left.\mathrm{B}_{4} \mathrm{Na}_{2} \mathrm{O}_{7} \cdot 10 \mathrm{H}_{2} \mathrm{O}\right)$ and $45 \mathrm{~S} 5\left(45 \mathrm{SiO}_{2} .24 \mathrm{CaO} .5 \mathrm{SrO} .24 .5 \mathrm{Na}_{2} \mathrm{O}\right.$ and $\left.6 \mathrm{P}_{2} \mathrm{O}_{5}\right)$ bioactive glass respectively. The filled cavities were detected at 15 and 30 days after implantation and histological analysis, microchemical and histomorphometry measurements were taken. At 15 days boron-based 45S5 exhibited significantly high neoformed bone tissue around the particles and high $\mathrm{Ca}$ : $\mathrm{P}$ ratio than $45 \mathrm{~S} 5$. However, at 30 day, no significant difference was observed. Thus, experimental bioactive glass demonstrates to provide a scaffolding site for osteoprogenitor cells and it also simulates rate of bone formation by osteoblasts. Same author's group added 6\% $\mathrm{SrO}$ in $45 \mathrm{~S} 5$ $\left(45 \mathrm{SiO}_{2} \cdot 18.5 \mathrm{CaO} .6 \mathrm{SrO} .24 .5 \mathrm{Na}_{2} \mathrm{O}\right.$ and $\left.6 \mathrm{P}_{2} \mathrm{O}_{5}\right)$ and implanted in rat's tibia ( $1.5 \mathrm{~mm}$ diameter) for 30 days. The histomorphometric analysis showed that no significant difference was found with $45 \mathrm{~S} 5$ after implantation, similarly no significant difference was observed in $\mathrm{Ca}$ : $\mathrm{P}$ ratio. ${ }^{12}$

A group of researchers created bilateral noncritical size ( $2.5 \mathrm{~mm}$ diameter) bone (upper third of the tibia) defects in Wistar rats, which were filled for 21 days with Bioglass ${ }^{\circledR}$ $45 \mathrm{~S} 5$ and Biosilicate-based bioactive glass $\left(40-50 \% \mathrm{SiO}_{2}\right.$, $20-25 \% \mathrm{Na}_{2} \mathrm{O}, 20-26 \% \mathrm{CaO}, 3-7 \% \mathrm{P}_{2} \mathrm{O}_{5}$; wt \%). The biomechanical analysis in this study showed similar biomechanical properties for defects filled with Biosilicate and intact cortical bone while exhibiting higher stiffness
(C) Copyright with permission, Molecular biologic comparison of new bone formation and resorption on microrough and smooth bioactive glass microspheres. J Biomed Mater Res Part B, Appl Biomater. 2003; 65(1): 163-170.

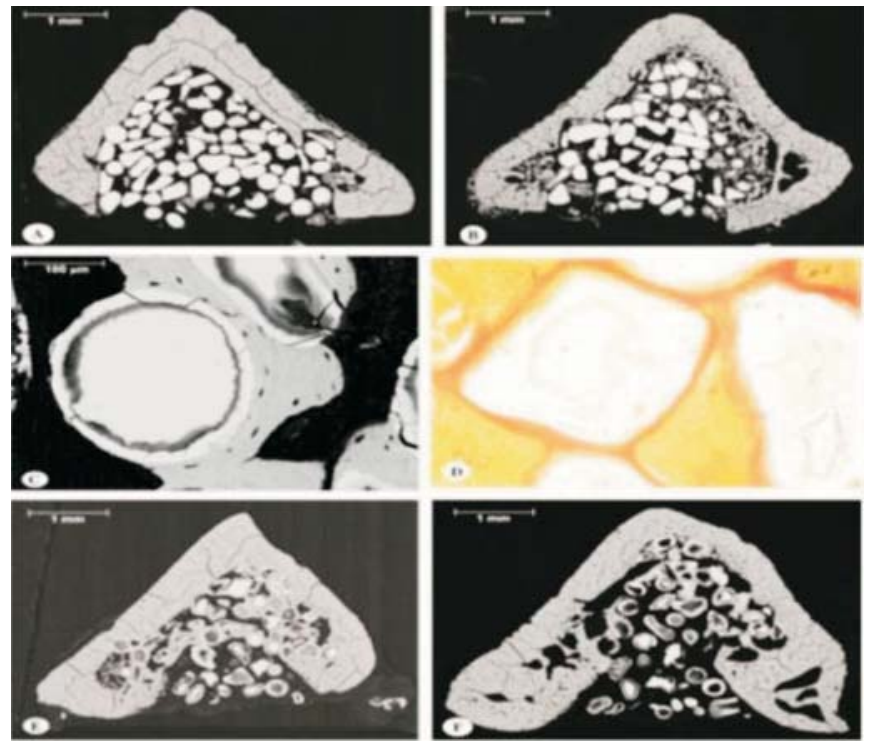

Fig 4: (A)-(C), (E), and (F) Backscattered electron image (BEI)-SEM micrographs and (D) van Gieson stained section demonstrating bone regeneration inside medullary cavity of the rat proximal tibia filled with bioactive glass microspheres: (A) at 1 week, microroughened surface; (B) at 1 week, control surface At 1 week, no apparent differences were seen between the two sides in primary bone healing response, which included formation of immature woven new bone within the medullary canal; (C) at 2 weeks, microrough surface; (D) at 2 weeks, microroughened surface; At 2 weeks, the amount of new bone remained at the same level on the microroughened side and on the smooth control side. New bone formation occurred from the endosteal surface of the cortical bone. In addition, in situ osteogenesis was observed between the bioactive glass microspheres and on their surfaces. (E) at 8 weeks, microroughened surface; (F) at 8 weeks, control surface, at 8 weeks, the amount of new bone had almost doubled, but there were no significant differences between the two sides microroughened side and smooth control side. (image taken after permission from authors)

values than unfilled bone defects. Where, higher number of osteoblasts per unit of tissue area was observed with Biosilicate group than Bioglass 45S5 group indicating better. ${ }^{37,38}$ In another study, cortical holes $(2.8 \mathrm{~mm}$ and $1 \mathrm{~mm}$ diameter) were created into the anteromedial cortex of the tibia of the rat models, filling them with roughened and smooth bioactive glass $\left(\mathrm{SiO}_{2} 53 \%, \mathrm{Na}_{2} \mathrm{O} 6 \%, \mathrm{CaO} 20 \%\right.$, $\mathrm{K}_{2} \mathrm{O} 12 \%, \mathrm{MgO} 5 \%, \mathrm{P}_{2} \mathrm{O}_{5} 4 \%$ by weight) microspheres. The rats were sacrificed after 1,2, and 8 weeks of implantation and were analyzed with micro-Computerized Tomography, Scanning Electron Microscopy, radiography and histomorphometric analysis. Larger cortical defects remained unhealed at 8 weeks with non-significant difference. After 8 week, the amount of new bone had almost doubled as shown in Fig. 4. Similarly, results showed that mRNA levels 
had non-significant change after 1 week, where as after 2 weeks, bones with roughened bioactive glass had significantly higher levels of osteopontin expression, similar trend was observed after 8 weeks, where MMP-9 mRNA levels were significantly higher in bones with roughened bioactive glass suggesting greater bone formation with roughened bioactive glass which might be due to microroughening process that altered the chemical composition and more leaching. ${ }^{39}$

Aza et al ${ }^{40}$ implanted bioactive glass $\left(\mathrm{SiO}_{2}=54.5\right.$; $\mathrm{CaO}=15.0 ; \mathrm{Na}_{2} \mathrm{O}=12.0 ; \mathrm{MgO}=8.5 ; \mathrm{K}_{2} \mathrm{O}=4.0 ; \mathrm{P}_{2} \mathrm{O}_{5}=6.0$, weight percentage) granules into diaphysis of left tibia of male Sprague-Dawley rats with average pore size was 100 $\mu \mathrm{m}$. The rats were sacrificed after 6,8 and 12 weeks and implants were excised. The results showed that after 6 weeks, the bioactive glass implants were well integrated with bone tissues. After 8 weeks, significant surface roughness was observed and a new calcium phosphate layer formed. At 12 weeks, a well-structured calcium phosphate phase was observed and results indicated mature bone with stoichiometric $\mathrm{Ca} / \mathrm{P}$ ratio of natural bone.

\section{CONCLUSION}

Bioactive glass materials have shown excellent biocompatibility and with inherent properties of bone regeneration can be considered as materials of choice. Along with tissue regeneration, this material has an additional properties of osteogenic and angiogenic properties. This review showed that bioactive glass supported cell adhesion, proliferation, and osteogenic differentiation. Studies showed that bioactive glass were non-toxic and enhanced metabolic and mitochondrial activity. Though, there are few studies on tibial defect regeneration, where modified bioactive glass materials have been used, but showed excellent results. Improvisation in composition and synthesis process can enhance the abilities of revascularization, differentiation, enzyme activity, and osteoblast adhesion. Bioactive glass also act as a stimuli to allow angiogenesis i.e. blood vessel formation and revascularization. In future, it is important to explore the role of nano-bioactive glass particles in tibial defect.

\section{CONFLICT OF INTEREST}

None declared

\section{REFERENCES}

1. Dimitriou R, Jones E, McGonagle D, Giannoudis PV. Bone regeneration: current concepts and future directions. BMC Med. 2011; 9:66.

https://doi.org/10.1186/1741-7015-9-66
2. Schmitz JP, Hollinger JO. The critical size defect as an experimental model for craniomandibulofacial nonunions. Clin Orthoped \& Related Res. 1986; 205: 299-08.

https://doi.org/10.1097/00003086-198604000-00036

3. Vajgel A, Mardas N, Farias BC, Petrie A, Cimões R, Donos N. A systematic review on the critical size defect model. Clin Oral Implant Res. 2014; 25: 879-93.

https://doi.org/10.1111/clr.12194

4. Aichelmann-Reidy ME, Reynolds MA. Predictability of clinical outcomes following regenerative therapy in intrabony defects. J Periodont. 2008; 79: 387-93.

https://doi.org/10.1902/jop.2008.060521

5. Young CS, Terada S, Vacanti JP, Honda M, Bartlett JD, Yelick PC. Tissue engineering of complex tooth structures on biodegradable polymer scaffolds. J Dent Res. 2002;81:695-700.

https://doi.org/10.1177/154405910208101008

6. Fishman JA. Miniature swine as organ donors for man: Strategies for prevention of xenotransplant-associated infections.

Xenotransplantation. 1994;1:47-57.

https://doi.org/10.1111/j.1399-3089.1994.tb00049.x

7. Vang P. Advantages and disadvantages between allograft versus autograft in anterior cruciate ligament replacement. Doctoral Thesis, Wichiata State University, 2006.

8. Vishwakarma A, Sharpe P, Shi S, Ramalingam M. Stem cell biology and tissue engineering in dental sciences: Academic Press; 2014. https://doi.org/10.1016/B978-0-12-397157-9.00001-1

9. Green DW, Goto TK, Kim K-S, Jung H-S. Calcifying tissue regeneration via biomimetic materials chemistry. J Royal Soc Interfac. 2014; 11(101): 20140537.

https://doi.org/10.1098/rsif.2014.0537

10. Navarro M, Michiardi A, Castano O, Planell J. Biomaterials in orthopaedics. J Royal Soc Interfac. 2008;5:1137-58.

https://doi.org/10.1098/rsif.2008.0151

11. Wei J, Wang J, Liu X, Ma J, Liu C, Fang J, et al. Preparation of fluoride substituted apatite cements as the building blocks for tooth enamel restoration. Appl Surf Sci. 2011; 257:7887-92. https://doi.org/10.1016/j.apsusc.2011.04.067

12. Jackson CM, Esnouf MP, Winzor DJ, Duewer DL. Defining and measuring biological activity: applying the principles of metrology. Accred \& Qual Assur. 2007;12: 283-94.

https://doi.org/10.1007/s00769-006-0254-1

13. Sarin S, Rekhi A. Bioactive glass: A potential next generation biomaterial. SRM J Res Dent Sci. 2016;7:27. https://doi.org/10.4103/0976-433X.176482

14. Erasmus EP, Johnson OT, Sigalas I, Massera J. Effects of Sintering Temperature on Crystallization and Fabrication of Porous Bioactive Glass Scaffolds for Bone Regeneration. Sci Rep. 2017;7:6046. https://doi.org/10.1038/s41598-017-06337-2 
15. Khan A, Hussain A, Sidra L, Sarfraz Z, Khalid H, Khan M, et al. Fabrication and in vivo evaluation of hydroxyapatite/carbon nanotube electrospun fibers for biomedical/dental application. Mater Sci Eng C. $2017 ; 80: 387-96$.

https://doi.org/10.1016/j.msec.2017.05.109

16. Cornell CN. Osteoconductive materials and their role as substitutes for autogenous bone grafts. The Orthoped Clin North Am. 1999; 30: 591-8.

https://doi.org/10.1016/S0030-5898(05)70112-7

17. Shah AT, Batool M, Chaudhry AA, Iqbal F, Javaid A, Zahid S, et al. Effect of calcium hydroxide on mechanical strength and biological properties of bioactive glass. J Mech Behav Biomed Mater. 2016; 61: 617-26.

https://doi.org/10.1016/j.jmbbm.2016.03.030

18. Hench LL, Splinter RJ, Allen W, Greenlee T. Bonding mechanisms at the interface of ceramic prosthetic materials. J Biomed Mater Res. 1971; 5: 117-41.

https://doi.org/10.1002/jbm.820050611

19. Gatti A, Yamamuro T, Hench L, Andersson O. In-vivo reactions in some bioactive glasses and glass-ceramics granules. Cells \& Mater. $1993 ; 3: 5$

20. Andersson Ö, Kangasniemi I. Calcium phosphate formation at the surface of bioactive glass in vitro. J Biomed Mater Res. 1991; 25: 1019-030.

https://doi.org/10.1002/jbm.820250808

21. Silver IA, Deas J, Erecinska M. Interactions of bioactive glasses with osteoblasts in vitro: effects of 45S5 Bioglass ${ }^{\circledR}$, and $58 \mathrm{~S}$ and $77 \mathrm{~S}$ bioactive glasses on metabolism, intracellular ion concentrations and cell viability. Biomaterials. 2001; 22: 175-85.

https://doi.org/10.1016/S0142-9612(00)00173-3

22. Valerio P, Pereira MM, Goes AM, Leite MF. The effect of ionic products from bioactive glass dissolution on osteoblast proliferation and collagen production. Biomaterials. 2004;25:2941-8. https://doi.org/10.1016/j.biomaterials.2003.09.086

23. Bellantone M, Coleman NJ, Hench LL. Bacteriostatic action of a novel four-component bioactive glass. J Biomed Mater Res Part A. 2000; 51: 484-90.

https://doi.org/10.1002/1097-4636(20000905)51:3<484::AID-JBM24 $>3.0 . \mathrm{CO} ; 2-4$

24. Wilson J, Low SB. Bioactive ceramics for periodontal treatment: comparative studies in the Patus monkey. J Appl Biomater. 1992; 3: 123-9.

https://doi.org/10.1002/jab.770030208

25. Hench LL, Jones JR. Bioactive glasses: frontiers and challenges. Frontiers in Bioeng \& Biotech. 2015;3. https://doi.org/10.3389/fbioe.2015.00194

26. Gorustovich A, Rosenbusch M, Guglielmotti MB. Characterization of bone around titanium implants and bioactive glass particles: an experimental study in rats. Int J Oral \& Maxillofac Implant. 2002; $17: 644-50$

27. Kucukkolbasi H, Mutlu N, Isik K, Celik I, Oznurlu Y. Histological evaluation of the effects of bioglass, hydroxyapatite, or demineralized freeze-dried bone, grafted alone or as composites, on the healing of tibial defects in rabbits. Saudi Med J. 2009; 30: 329-33.

28. Gasparini Ribeiro LL, Bosco AF, Nagata MJH, Nascimento de Melo LG. Influence of bioactive glass and/or acellular dermal matrix on bone healing of surgically created defects in rat tibiae: a histological and histometric study. Int J Oral \& Maxillofac Implant. 2008;23: 811-17

29. Newman SD, Lotfibakhshaiesh N, O'Donnell M, Walboomers XF, Horwood N, Jansen JA, et al. Enhanced osseous implant fixation with strontium-substituted bioactive glass coating. Tissue Eng Part A. 2014; 20(13-14): 1850-7.

https://doi.org/10.1089/ten.tea.2013.0304

30. Veis AA, Dabarakis NN, Parisis NA, Tsirlis AT, Karanikola TG, Printza DV. Bone regeneration around implants using spherical and granular forms of bioactive glass particles. Implant Dent. 2006; 15 : 386-94.

https://doi.org/10.1097/01.id.0000243317.57261.86

31. Kim J-N, Lee J-Y, Shin K-J, Gil Y-C, Koh K-S, Song W-C. Haversian system of compact bone and comparison between endosteal and periosteal sides using three-dimensional reconstruction in rat. Anat Cell Biol. 2015; 48: 258-61.

https://doi.org/10.5115/acb.2015.48.4.258

32. Cui X, Zhao C, Gu Y, Li L, Wang H, Huang W, et al. A novel injectable borate bioactive glass cement for local delivery of vancomycin to cure osteomyelitis and regenerate bone. J Mater Sci Mater Med. 2014; 25: 733-45.

https://doi.org/10.1007/s10856-013-5122-z

33. Fu Q, Huang W, Jia W, Rahaman MN, Liu X, Tomsia AP. Threedimensional visualization of bioactive glass-bone integration in a rabbit tibia model using synchrotron X-ray microcomputed tomography. Tissue Eng Part A. 2011; 17: 3077-084.

https://doi.org/10.1089/ten.tea.2011.0068

34. Zhang X, Jia W, Gu Y, Xiao W, Liu X, Wang D, et al. Teicoplaninloaded borate bioactive glass implants for treating chronic bone infection in a rabbit tibia osteomyelitis model. Biomaterials. 2010; 31: 5865-74.

https://doi.org/10.1016/j.biomaterials.2010.04.005

35. Moimas L, Biasotto M, Lenarda RD, Olivo A, Schmid C. Rabbit pilot study on the resorbability of three-dimensional bioactive glass fibre scaffolds. Acta Biomater. 2006; 2:191-9.

https://doi.org/10.1016/j.actbio.2005.09.006

36. Gorustovich AA, Steimetz T, Cabrini RL, Porto López JM. Osteoconductivity of strontium-doped bioactive glass particles: A histomorphometric study in rats. J Biomed Mater Res Part A. 2010; 92:232-7.

https://doi.org/10.1002/jbm.a.32355 
37. Granito RN, Ribeiro DA, Rennó ACM, Ravagnani C, Bossini PS, Peitl-Filho O, et al. Effects of biosilicate and bioglass 45S5 on tibial bone consolidation on rats: a biomechanical and a histological study. J Mater Sci Mater Med. 2009;20:2521.

https://doi.org/10.1007/s10856-009-3824-z

38. Granito RN, Renno AC, Ravagnani C, Bossini PS, Mochiuti D, Jorgetti $\mathrm{V}$, et al. In vivo biological performance of a novel highly bioactive glass-ceramic (Biosilicate $(\mathrm{R})$ ): A biomechanical and histomorphometric study in rat tibial defects. J Biomed Mater Res Part B, Appl Biomater. 2011;97:139-47.

https://doi.org/10.1002/jbm.b.31795
39. Itala A, Valimaki VV, Kiviranta R, Ylanen HO, Hupa M, Vuorio $\mathrm{E}$, et al. Molecular biologic comparison of new bone formation and resorption on microrough and smooth bioactive glass microspheres. J Biomed Mater Res Part B, Appl Biomater. 2003;65:163-70. https://doi.org/10.1002/jbm.b.10529

40. De Aza PN, Luklinska ZB, Santos C, Guitian F, De Aza S. Mechanism of bone-like formation on a bioactive implant in vivo. Biomaterials. 2003;24:1437-45.

https://doi.org/10.1016/S0142-9612(02)00530-6 